\title{
Pleomorphic Adenoma of the Upper Lip
}

\section{Üst Dudakta Yerleşim Gösteren Pleomorfik Adenom}

\author{
Ülkü KÜÇÜK', Serdar TAN² \\ Departments of ${ }^{1}$ Pathology and ${ }^{2}$ Otolaryngology, M.H. Kütahya State Hospital, KÜTAHYA, TURKEY
}

\begin{abstract}
Pleomorphic adenoma is the most common neoplasm of the salivary glands and is most commonly located in the parotis followed by the submandibular glands. Its localization in the minor salivary glands is mostly reported in the palate. Few publications report pleomorphic adenoma cases located in the lip.

We present a 35-year-old male patient with a pleomorphic adenoma located in the upper lip.
\end{abstract}

Key Words: Pleomorphic adenoma, Lip, Salivary gland neoplasms, Head and neck neoplasms

\section{INTRODUCTION}

Pleomorphic adenoma is the most common tumor of the salivary glands $(1,2)$. The lesion is seen most commonly in females in their fourth decade but can also be seen in children and at advanced ages (3). The tumor is most commonly located in the parotid gland (75\%) followed by the submandibular gland (5-10\%) and minor salivary glands (4). It most commonly affects the palatal glands among the minor salivary glands (4). The definite etiology is not known. Cytogenetic and molecular studies have reported that it is of epithelial origin with chromosomal abnormalities at $8 \mathrm{q} 12$ and $12 \mathrm{q} 25$ (5). The patients present with a painless and slow-growing mass (4). We present a pleomorphic adenoma in the upper lip, which is a rarely reported location.

\section{CASE REPORT}

A 35-year-old male patient presented at our hospital complaining of a swelling in his upper lip. His history revealed that he had suffered facial trauma 10 years ago and this had resulted in serious injury of his lips. A mass had appeared in the right half of the upper lip causing a swelling under the mucosa three years after this event and had grown slowly in the last seven years. The patient had not suffered any pain and had now presented at the clinic due to limitation of daily

Received : 09.11.2009

Accepted : 14.04.2010

\section{ÖZ}

Pleomorfik adenom tükrük bezlerinin en sık görülen tümörüdür. En sık parotiste görülür, bunu submandibuler bezler takip eder. Minör tükrük bezlerinde ise öncelikle palatal yerleşim bildirilmektedir. Yayınlarda çok az sayıda dudak yerleşimli pleomorfik adenom olgusu bulunmaktadır. 35 yaşında erkek hastada, üst dudakta yerleşim gösteren bir pleomorfik adenom olgusunu sunuyoruz.

Anahtar Sözcükler: Pleomorfik adenom, Dudak, Tükrük bezi tümörleri, Baş-boyun tümörleri

activities and the physical appearance. There was no history of any other disease and the routine laboratory test results were within normal limits. Clinical examination revealed a mobile painless mass of firm consistency that was located under the mucosa of the upper lip and caused a swelling. A mucosa incision was made under local anesthesia and the mass, found to be encapsulated, was totally excised and sent to our department. The specimen we obtained was a gray-white lesion of firm consistency with a surrounding capsule, nodular in appearance and $1.8 \times 1.5 \times 1.5 \mathrm{~cm}$ in size. The sectional surface of the lesion was solid and gray-white to tan in color with occasional cystic areas (Figure 1).

The histological section prepared from the material showed that the lesion had a thin fibrous capsule and consisted of epithelial and stromal components. The stroma had a fibromyxoid appearance. Mature adipocytes distributed in the stroma were observed. The epithelial component formed gland-like structures in places and some of these glands were dilated in a way that could cause a cystic appearance macroscopically. Amorphous eosinophilic material was observed in the lumen of most glands while some gland-like structures showed squamous metaplasia and keratin production. There were also plasmocytoid/epithelial cells distributed within the stroma as occasional layers and concentrated around the glands

Correspondence: Ülkü KÜÇÜK

Department of Pathology, M.H. Kütahya State Hospital,

KÜTAHYA, TURKEY

E-mail: kucukulku@hotmail.com Phone: +90 4762260303 
in the sections (Figure 2). The cytokeratin (CK, Scytek, A00098) immunohistochemical marker showed diffuse positive staining of the epithelial cells (Figure 3). S-100 (NeoMarkers, MS-296-R7) and smooth muscle actin (SMA, NeoMarkers, MS-113-R7) immunohistochemical markers showed staining consistent with myoepithelial cells in the plasmocytoid-appearing cells (Figure 4-5). A diagnosis of pleomorphic adenoma was made with these findings.

\section{DISCUSSION}

Salivary gland tumors are rare and constitute $2-6.5 \%$ of all head and neck tumors (6). Pleomorphic adenoma is the most common tumor of the salivary glands $(1,2,6)$. These tumors make up $70 \%$ of the parotis tumors, $50 \%$ of the submandibular gland tumors and $45 \%$ of the minor salivary gland tumors (4).

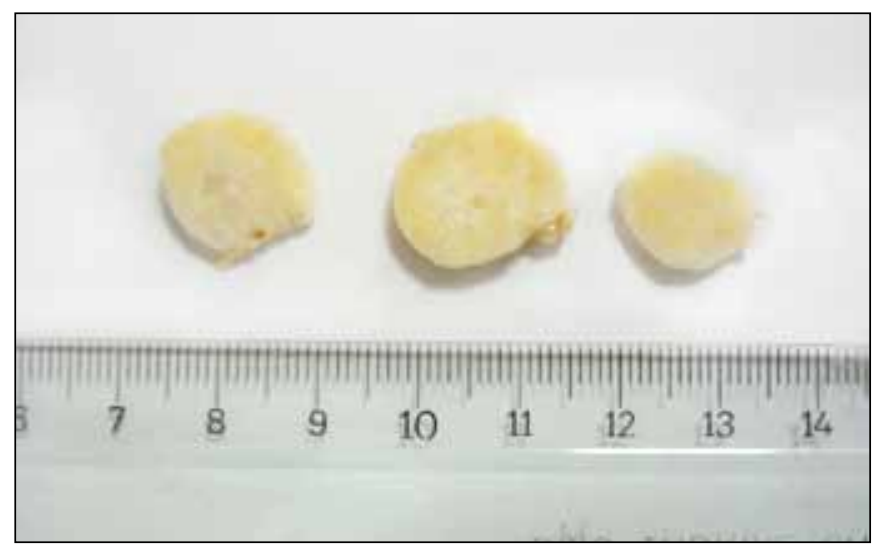

Figure 1: Solid, gray-white to tan pleomorphic adenoma with cystic areas on the section surface.

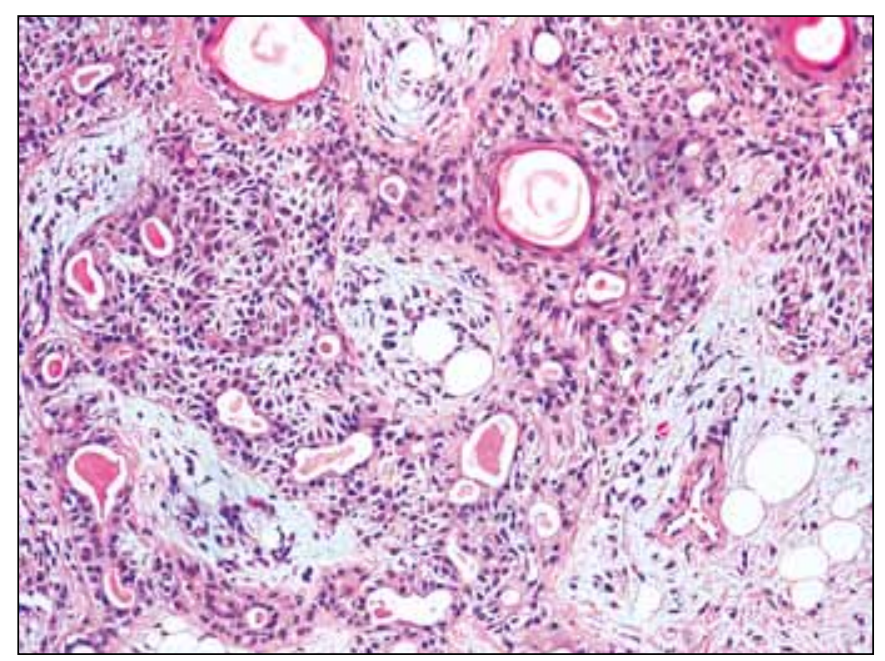

Figure 2: Pleomorphic adenoma with cord-like tubular structures showing squamous metaplasia in one section and plasmocytoid epithelial cells distributed in the stroma with mature adipocytes (H\&E; x200).

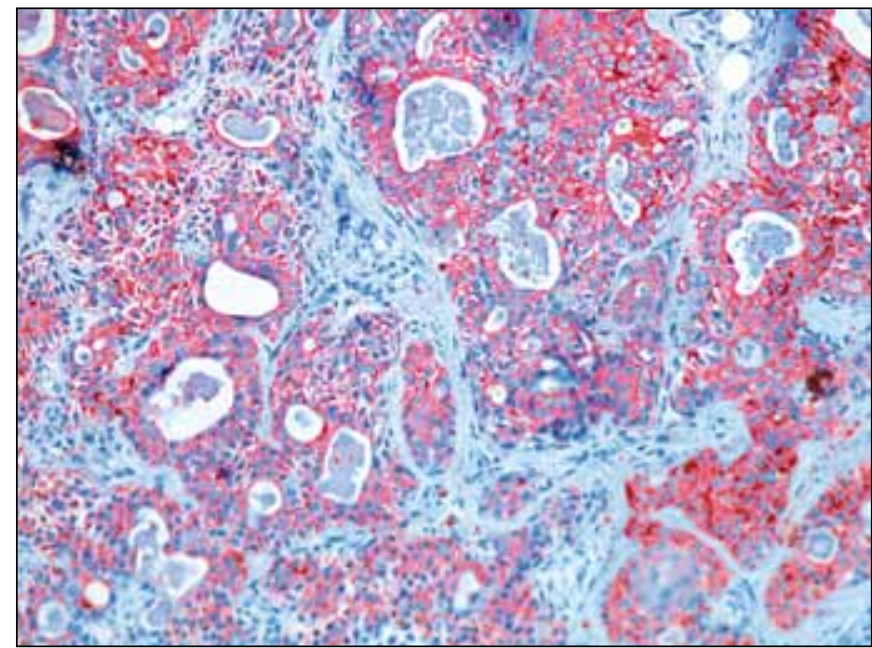

Figure 3: Diffuse membranous immunostaining in all epithelial cells with cytokeratin $(\mathrm{x} 200)$.

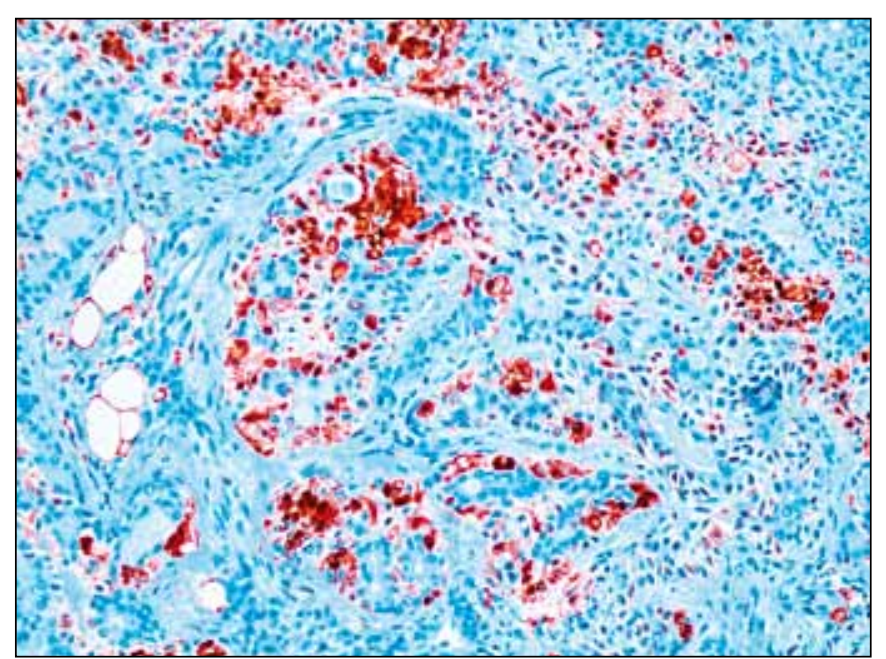

Figure 4: Cytoplasmic immunostaining in the plasmacytoid myoepithelial cells with S-100 (x200).

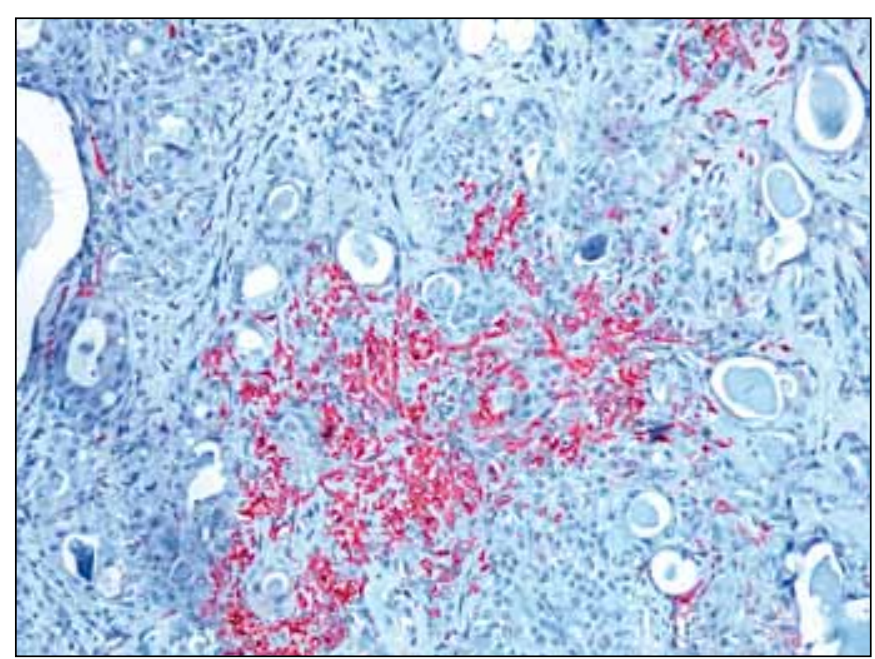

Figure 5: Membranous immunostaining in the plasmacytoid myoepithelial cells with smooth muscle actin (x200). 
The definite etiology is not known. However, cytogenetic and molecular studies have shown an epithelial origin for the tumor with chromosomal abnormalities in $8 \mathrm{q} 12$ and $12 \mathrm{q} 25$ (5). The incidence and distribution of minor salivary gland tumors have been reported to vary with race and geographic region (7). Most studies report that minor salivary gland tumors are more common in females than males and that the tumors seen in women tend to be benign while other studies state that this gender difference is related to ethnic differences (8). This second group of studies report that minor salivary gland tumors are more common in black females while there is no gender difference in the white race (8).

Most studies have found minor salivary gland tumors to be palatal in location and $40-80 \%$ of all tumors are reported to arise from this region $(6,8,9)$. The pleomorphic adenomas developing from minor salivary glands are also most commonly located in the palatal region (60-65\%). This is followed by the cheek (15\%), tongue and oral base (4). Jaber MA (7) has reported from a study on 75 patients with intraoral minor salivary gland tumors that 15 of the 29 benign tumors were palatal in location with only four on the upper lip and one on the lower lip. The most common symptom of tumors developing from the minor salivary glands is a swelling arising inside the mouth. Less common symptoms are ulceration, tenderness, and difficulty talking (7).

Macroscopically, the tumor is seen as a well-limited, roundoval, nodular mass with firm consistency. It is usually encapsulated. A capsule is usually not present in tumors developing from the minor salivary glands and lesions microscopically rich in stroma (1). The appearance of the tumor's sectional surface varies according to the epithelium to stroma ratio. The stroma has a shiny and translucent image if it is rich in cartilage islands (2).

A typical pleomorphic adenoma has a biphasic microscopical appearance with epithelial and stromal components (2). Ductal epithelial glands make up glandular structures and cystic structures of various sizes. Myoepithelial cells can be of very different cytomorphological appearances such as spindle-shaped, plasmacytoid, squamoid, starshaped and basaloid. These cells can be distributed separately or may form islands, solid sheets or trabeculae (1). Myxochondroid changes are the most common change in the stroma. However, the stroma can be loose-myxoid or dense-hyalinized depending on the rate of collagenization. The cartilaginous differentiation areas commonly seen in tumors originating from the parotid and submaxillary glands are seen much less frequently in tumors originating from the minor salivary glands $(1,2)$. The ductal epithelial component is positive with keratin and EMA on immunohistochemical investigation. The myoepithelial component stains positively with keratin, actin, myosin, other smooth muscle-specific proteins, fibronectin and S-100 (2).

There have been various studies investigating what keratin types are expressed in the epithelial and myoepithelial component. Ogawa et al. (10) have evaluated the immunohistochemical staining characteristics of tumor cells in pleomorphic adenoma and found ductal epithelial cells to stain positively with CK19 while there was variable CK14 staining. They also report that peripherally-located myoepithelial tumor cells stain positive for CK14 and that some of these CK14-positive cells, usually those that are spindle- or star-shaped, are also positive for alpha SMA (10).

The differential diagnosis of intraoral solid and asymptomatic nodules includes minor salivary gland tumors and benign and malignant mesenchymal tumors (11). The minor salivary gland tumor myoepithelioma and basal cell adenoma are the primary considerations in the differential diagnosis. Myoepithelial cells are dominant and ductal structures are very rare in myoepithelioma. Basal cell adenoma is generally palatal in location and has no capsule (1). Lipoma, neurofibroma and other benign mesenchymal tumors should also be considered for the differential diagnosis if the lesion has developed in the buccal mucosa, lip or tongue. A mobile lesion with a capsule would indicate a possible benign nature but a biopsy is essential for definite diagnosis (11).

It is suggested that the lesion be removed together with the surrounding normal tissue for pleomorphic adenoma treatment. Recurrence develops in $45 \%$ of lesions that have been removed with simple tumor enucleation as in our case (1). It is believed that the reason for recurrence is rupture of the tumor capsule or incomplete excision of the lesion during the procedure and leaving behind live residual tumor cells (12). Our case is also being followed-up due to the risk of recurrence.

\section{REFERENCES}

1. Torske K: Benign neoplasms of the salivary glands. In: Thompson LDR, Goldblum JR (eds) Head and Neck Pathology. Philadelphia, Churchill Livingstone, 2006, 295-319

2. Rosai J: Major and minor salivary glands. In: Rosai and Ackerman's Surgical Pathology. Edinburg, London,New York, Oxford, Philadelphia, St Louis, Sydney, Toronto, Mosby, 2004, 873-900

3. Krolls SO, Trodahl JN, Boyers RC: Salivary gland lesions in children. A survey of 430 cases. Cancer 1972, 30:459-469 
4. Huvos AG, Paulino AFG: Salivary Glands. In: Mills SE, Carter D, Reuter VE, Greenson JK, Stoler MH, Oberman HA (eds): Sternberg's Diagnostic Surgical Pathology. Philadelphia, Lippincott Williams\&Wilkins, 2004, 933-962

5. Farina A, Pelucchi S, Grandi E, Carinci F: Histological subtypes of pleomorphic adenoma and age-frequency distribution. Br J Oral Maxillofac Surg 1999, 37:154-155

6. Auclair PL, Ellis GL, Gnepp DR, Wenig BM, Janney CG: Salivary gland neoplasms: general considerations. In: Ellis GL, Auclair PL, Gnepp DR (eds): Surgical Pathology of the Salivary Glands. Philadelphia, Saunders, 1991, 135-164

7. Jaber $\mathbf{M A}$ : Intraoral minor salivary gland tumors: a review of 75 cases in a Libyan population. Int J Oral Maxillofac Surg 2006, 35:150-154

8. Toida M, Shimokawa K, Makita H, Kato K, Kobayashi A, Kusunoki Y, Hatakeyama D, Fujitsuka H, Yamashita T, Shibata T: Intraoral minor salivary gland tumors: a clinicopathological study of 82 cases. Int J Oral Maxillofac Surg 2005, 34:528-532
9. Jansisyanont P, Blanchaert RH Jr, Ord RA: Intraoral minor salivary gland neoplasm: a single institution experience of 80 cases. Int J Oral Maxillofac Surg 2002, 31:257-261

10. Ogawa Y, Toyosawa S, Ishida T, Ijuhin N: Keratin 14 immunoreactive cells in pleomorphic adenomas and adenoid cystic carcinomas of salivary glands. Virchows Arch 2000, 437: 58-68

11. Jorge J, Pires FR, Alves FA, Perez DE, Kowalski LP, Lopes MA, Almeila OP: Juvenile intraoral pleomorphic adenoma: report of five cases and review of the literature. Int J Oral Maxillofac Surg 2002, 31:273-275

12. Daniels JS, Ali I, Al Bakri IM, Sumangala B: Pleomorphic adenoma of the palate in children and adolescents: a report of 2 cases and review of the literature. J Oral Maxillofac Surg 2007, 65:541-549 